\title{
PAK MULTIKULTURAL DALAM BINGKAI ERA REVOLUSI INDUSTI 4.0
}

\author{
Novistianus D. Salenussa, Beatrix J.M. Salenussa \\ salenussanovistianus@gmail.com
}

\begin{abstract}
This writing aims to provide ideas for Christian Religion Education (PAK) in the frame of the industrial revolution 4.0 era to answer the multicultural context in Maluku. This writing uses qualitative description approach with an inductive and hermeneutic approach to analyze the data relating to the multicultural context of society in Maluku and the Role of Christian Religious Education to help people to openly accept plurality in the era of the industrial revolution 4.0 This illustrates that the role of religion can be used as a guide in an effort to create a meaningful, peaceful and dignified life. In line with that, education is used as an effort for human to be able to develop their potential through a learning process that is known and recognized by the community, to be creative in conveying learning which increasingly plays a central role in cyber technology in human life, so that in the continuation of Christian Religious Education can also be used as learning in an effort to increase spiritual potential, in order to form people who have faith, character, and noble according to the challenges of the growing era
\end{abstract}

Keyword: Christian Religion Education (PAK), Multicultural, Industrial Revolution 4.0

\section{Pengantar}

Masyarakat Indonesia terdiri dari berbagai corak suku bangsa dengan berbagai agama yang dianutnya. Pluralitas multikultural ini perlu diterima sebagai kenyataan, di mana pluralitas suku bangsa dan agama dalam masyarakat Indonesia, berha-sil di atasi dengan ideologi negara, yaitu Pancasila. Itu berarti bahwa pancasila, melampaui Multikultural dan pluralitas. Hal inilah yang perlu dipahami dalam kemajemukan masyarakat yang multikultural yakni menganut berbagai agama, terikat dan hidup bersama, serta menjalin persatuan dan kesatuan bangsa da-lam wadah negara kesatuan republik Indonesia.

Kemajemukan demikian merupa-kan identitas bersama yang olehnya suku-suku yang menganut berbagai agama itu sendiri tidak lagi memahami dirinya masing-masing berbeda menurut ukuran suku bang-sa atau agamanya terlepas dari kenyataan sebagai masyarakat Indo-nesia. Dengan kata lain sikap dan cara berpikir pragmatis tentang hubungan antara realitas kemajemu-kan masyarakat dan realitas suku bangsa yang menganut berbagai agama sudah tidak mungkin diperta-hankan lagi. Di dalam praktek kehi-dupan masyarakat, masalah kemajemukan suku bangsa yang menganut berbagai agama itu belum dapat diselesaikan sepenuhnya. Realitas dalam praktek, masalah itu diakui baik oleh masyarakat maupun pemerintah. Pengakuan itu dinya-takan dalam istilah yang melukiskan masalah itu yaitu istilah SARA (suku, agama, ras dan adat). Masa-lah SARA dalam masyarakat lintas kultural yang majemuk agamanya ini tidak jarang meruncing pada konflik antar agama. Konflik sosial tersebut yang sifatnya laten sebagai-mana terjadi dalam beberapa tahun belakangan ini rupanya disulut oleh sikap dan pola pikir agama itu sendiri. Cuatan itu masih terasa dalam kehidupan masing-masing agama yang saling menutup diri; masing-masing hidup dalam dunia-nya sendiri-sendiri, komunikasi ter-batas pada hubungan hidup sehari-hari; belum terasa pergaulan antara pemeluk-pemeluk agama itu, sikap dan pola pikir "terbuka" untuk sa-ling menerima dan mengakui keberadaan masing-masing (Pamungkas, C : 2014).

Di Indonesia, Pendidikan Agama Kristen sering dimengerti secara sempit sehingga agama seakan man-deg dan tidak menjadi agen peru-bahan sosial yang signifikan, oleh sebab itu perbedaan agama sering membuat konflik sosial yang tak habishabisnya. Hal ini terjadi juga di Maluku, yang kaya akan rempah-rempah, dengan adat kekerabatan-nya seperti pela dan gandong. Realitas ini menunjukkan pada sebuah eksistensi sosial masyarakat yang pluralis multikultural telah hancur akibat idealisme agama terlalu kuat. Salah satu cara yang ditempuh adalah dengan dilaksana-kan pendekatan adat. Di mana-mana orang melakukan panas pela, pelaksanaan pelantikan raja negeri dengan melibatkan negeri-negeri pela dan gandong. Pelaksanaan upacara adat yang berlangsung bukan saja untuk memenuhi tuntu-tan adat, tetapi juga ada maksud-maksud tertentu di dalamnya yakni menjalin hubungan yang telah retak antar masyarakat. Namun tetap saja harapan untuk berdamai tetap hampa sebab fanatisme agama mengalahkan segala bentuk tindakan yang didasari akal sehat (Tualeka Zn, H: 2015). 
Mempersatukan negara yang majemuk atau pluralitas adalah cita-cita luhur dari pendiri Republik Indonesia yakni dengan menjalin persekutuan dan kesatuan bangsa di negara yang multi pluralis. Salah satu model pembangunan masya-rakat kesatuan dalam persatuan bangsa adalah dengan menetapkan Burung Garuda sebagai lambang atau simbol bangsa. Lambang terse-but tersirat kalimat Bhineka Tunggal Ika. Istilah ini diambil dari khasanah Majapahit, bermacam ragam namun satu jua. Agaknya "morale", "inte-grasi" berbagai kelompok kebuda-yaan ini tidak hanya diharapkan bersatu, tetapi juga produktif di dalam kesatuannya, sehingga kese-rasian, keselarasan, keseimbangan selalu jadi sesanti yang mengkitinya. Bahkan terkadang jiwa persatuan dan kesatuan itu begitu bersemangat sehingga tidak sanggup lagi melihat perbedaan (Lestari :2015).

Di samping itu juga, sebelum Indonesia merdeka, para pemuda telah memberikan konstribusi pikir kepada bangsa dengan ikrar Sumpah Pemuda yang digelar pada tanggal 28 Oktober 1928. Menjalin keber-samaan bukan saja pada kedua hal tersebut, tetapi juga dalam rapat-rapat BPUPKI dan PPKI menjadi bukti sejarah yang yang dapat dilupakan dengan adanya penghapu-san tujuh kata tambahan dalam Pembukaan UUD 1945 (Dwintari, 2018). di sisi lain, perumusan tujuh kata dalam piagam Jakarta menun-jukkan pada kebencian Islam terhadap agama-agama lain dan secara khusus kepada Kristen (Muhammad Latif : 2005).

Menjalin kesatuan bangsa agar mendapatkan negara yang kuat dan utuh, bukan didasari atas satu agama atau dua agama tetapi aspek keberagaman agama yang ada dine-gara ini haruslah dilihat sebagai dimensi penting untuk mendirikan Negara Kesatuan Republik Indo-nesia (NKRI). Namun, penafsiran terhadap Kitab Suci sehingga muncullah gerakan-gerakan Islam garis keras yang mengobrak-abrik bangsa ini dengan teror bom maupun ledakan-ledakan bom yang ada. Di samping itu mereka juga membuat kekacauan di mana-mana dengan mempergunakan isu agama sebagai titik lemah sehingga meme-cahkan masyarakat Indonesia yang pluralis (Ode,S: 2015). Disadari juga bahwa plu-ralitas agama tak dapat dielakkan begitu saja, karena ada sifat dua muka yang melekat pada agama. Pada satu sisi, agama mempunyai nilai-nilai yang bersifat inklusif, universal dan transcending. Tetapi, di pihak lain, agama mengandung hal-hal yang bersifat eksklusif, partikular dan primordial (Ibrahim:2013). Dua wajah dari agama itulah yang menyebabkan adanya idealisme yang kuat terhadap agamanya. Hal ini juga merupakan pergumulan bangsa Indonesia dalam menghadap kemajemukan agama masyara-katnya.

Upaya untuk mengantisipasi gejala tersebut, maka hal yang sangat utama adalah mengembalikan kebudayaan masyarakat sesuai dengan karakternya masing-masing. Kebudayaan bangsa harus mendapat sorotan yang tajam dan bukan kebudayaan agama. Di lain pihak, menghormati kebudayaan daerahdaerah lain adalah hal yang sangat penting (Dwintari:2018). Dalam hubungan itu, maka hal yang sangat penting adalah memberikan Pendidikan Agama Kristen (PAK) multikultural bagi generasi muda gereja, yang dijalankan dengan tujuan untuk menyadarkan manusia bahwa saling mencela dan saling menuding antar agama itu tidak baik. Sehubungan dengan itu, PAK multikultural sebenarnya sangat penting disampaikan untuk memberikan pemahaman bagi generasi muda gereja agar dapat berkompetensi dalam memecahkan masalah dengan memberikan pena-naman multikultural yang benar untuk menghasilkan generasi muda gereja yang berkarakter, kreatif, inovatif, dan berintegritas guna menjunjung tinggi toleransi hidup berdasarkan nilai-nilai nasional bangsa Indonesia.

\section{Tinjauan Literatur Konsep PAK Multikultural}

Agama pada dasarnya sangat berperan penting dalam kehidupan seseorang. Hal ini dikatakan demikian, karena agama sendiri ber-hubungan dengan hidup rohani mau-pun keyakinan seseorang kepada Tuhan. Selain itu juga agama ber-peran sebagai pemandu dalam upaya mewujudkan suatu kehidupan yang bermakna, damai, dan bermartabat. Sejalan dengan itu, maka pendi-dikan yang merupakan usaha sadar untuk manusia dapat mengembang-kan potensi dirinya melalui proses pembelajaran dan cara untuk diakui oleh masyarakat. dengan demikian secara konsep berpikir pendidikan agama sebenarnya bermaksud bukan saja untuk meningkatkan potensi spiritual seseorang tapi juga membentuk pribadi seseorang menjadi manusia yang beriman dan mulia (Utomo,BS : 2017).

Pemahaman mengenai pen-didikan agama ini kemudian dalam konsep pendidikan agama Kristen pada hakikatnya lebih mengarah pada usaha 
yang dilakukan secara terencana dan kontinyu dalam upaya mengembangkan kemampuan para peserta didik dalam hal ini generasi muda gereja untuk melalui perto-longan Roh Kudus, mampu memahami dan menghayati kasih Allah dalam diri Yesus Kristus yang dinyatakan dalam hidup sehari-hari, baik terhadap sesama maupun ling-kungan hidupnya. Dengan begitu, maka proses pembelajaran pendi-dikan agama Kristen atau yang disingkat PAK ini, bermaksud untuk menunjuk pada keterpanggilan da-lam mewujudkan tanda-tanda ke-rajaan Allah dalam kehidupan pri-badi maupun sebagai bagian dari ko-munitas masyarakat.

Sejalan dengan itu, maka pendidikan multikultural lebih diarahkan pada suatu kebutuhan karena merupakan alat untuk mem-bina dunia yang aman dan sejahtera, dimana suku bangsa dalam suatu negara atau bangsa-bangsa di dunia dapat duduk bersama, saling menghargai, dan saling membantu (Suharsonon :2017). Prinsipnya, pendidikan multikultural adalah pendidikan yang menghargai perbedaan, dalam artian perbedaan tersebut tidak menjadi sumber konflik dan perpecahan. Sikap sa-ling toleransi inilah yang nantinya akan menjadikan keberagaman yang dinamis, kekayaan budaya yang menjadi jati diri dan karakter yang patut untuk dilestarikan.

Pendidikan multikultural ke-mudian dirumuskan sebagai wujud kesadaran tentang keanekaragaman Cultrul, hak-hak asasi manusia serta pengurangan atau penghapusan jenis prasangka atau prejudice untuk suatu kehidupan masyarakat yang adil dan maju (Lestari 2017)

Menurut pendapat (Tilaar:2017), pendidikan multikultural adalah pendidikan untuk meningkatkan penghargaan terhadap keragaman etnik dan budaya masyarakat. Hal ini menunjukkan bahwa konsep PAK multikultural dapat memberi-kan gambaran bahwa PAK mul-tikultural berperan sebagai Pendi-dikan Agama yang juga dapat mengambil bagian dalam pola pengem-bangan dalam membangun keadilan dan perdamaian berbasis multikul-tural sebagai sarana membangun kepercayaan, saling menghargai, sa-ling memberi dan menerima, saling menyesuaikan diri dan sebagainya berdasarkan nilai-nilai kearifan lokal dan budaya, yang menghadirkan ge-reja, mesjid, sekolah-sekolah, lem-baga kepemudaan dan masyarakat sebagai institusi-institusi yang dapat dijadikan wadah strategis dalam mempersiapkan diri sebagai agen-agen perdamaian dan aktor dalam membentuk komunitas iman lintas agama melalui aktifitas yang dila-kukan secara bersama-sama.

Hal ini menjelaskan bahwa pada dasarnya Pendidikan Agama Kristen, tidak hanya dilihat secara sempit sebagai pendidikan keagama-an tetapi sebagai Christian Edu-cation dimana ia berfungsi secara luas mencakup segala bentuk pelayanan gereja bagi sesama secara luas, dan oleh karena itu bertujuan untuk memanusiakan manusia men-jadi manusia sejati yang tinggi ilmu tetapi juga tinggi iman dan pengabdian terhadap bangsa dan negara, yang berperan memberi informasi ilmiah mengenai agama dalam konteks multikultural, mela-lui pembentukan komunitas lintas agama.

Pembentukan komunitas lintas agama inilah yang kemudian dijadikan sebagai bagian dari upaya pengembangan toleransi hidup antar umat beragama dalam konteks multicultural (Supriatin :2017). Sejalan dengan itu, maka peran penting PAK multikul-tural sangat dibutuhkan untuk disampaikan kepada generasi muda gereja, agar selalu menanamkan transformasi nilai-nilai Kristiani dalam kehidupannya, sehingga mampu memberikan ruang yang sama terhadap sesuatu hal yang berbeda dalam mengembangkan pemahaman Iman Kristiani sesuai dengan tingkat kemampuan serta daya kreativitas individu itu sendiri dengan memperlihatkan proses pengajarannya mela-lui metode, pendekatan, media, dan model yang dipilih sebagai alat untuk berkomunikasi sehingga apa yang nantinya disampaikan dapat menjadi motivasi yang bernilai positif dalam upaya mencapai tujuan PAK yakni; Memperkenalkan Allah Bapa, Anak dan Roh Kudus, serta karya-karya-Nya agar nantinya dapat bertumbuh dalam iman percaya kepada Allah sebagai Tuhan dan Juruselamat dalam konteks hidup yang multikultural (Nuhamara :2018).

\section{Metode}

Penelitian ini menggunakan metode diskriptifkualitatif, dengan pendekatan yang dipakai adalah pendekatan induktif agar diperoleh keakurasian data. Data-data yang diperoleh dikumpulkan, direfleksi-kan dan diabstraksikan dalam upaya membangun teori atas hasil penelitian (Moleong :2017). Penelitian ini ditujukan kepada generasi muda Kristen di Maluku.

Teknik analisis data menggunakan teknik kualitatif dengan pendekatan hermeneutik untuk membantu memberikan pena-jaman terhadap data 
lapangan dan data kepustakaan terutama yang berkaitan dengan bahan-bahan yang menggambarkan konteks multikul-tural di Maluku dan Peran Pen-didikan Agama Kristen dalam membentuk manusia yang bersedia terbuka menerima kepelbagaian (plurality) yang ada di era revolusi industri 4.0. Analisis data dalam penelitian ini menggunakan metafor, narasi dan semiotik sebagai langkah untuk menempatkan fakta atau kondisi PAK Multikultutral di Maluku menjadi data kualitatif terkait dengan persoalan penelitian.

\section{Hasil dan Pembahasan}

\section{PAK Multikultural Dalam Era Relovosi Industri 4.0}

Perubahan paradigma yang terjadi dalam saat ini dengan adanya pengaruh revolusi industri 4.0 memberikan dampak positif dengan semakin maju dan berkembangnya sistem pendidikan kita, akan tetapi di sisi yang lain juga memberikan dampak negatif bagi dunia pendi-dikan, apabila tidak mampu men-jawab tantangan yang muncul di era sekarang ini. Dampak negatif yang ditimbulkan saat ini berdampak pada kurangnya pemahaman mengenai pendidikan karakter bagi generasi muda kita saat ini. Kurangnya pemahaman mengenai pendidikan karakter ini berdampak terhadap lunturnya identitas diri sebagai anak bangsa, bahkan nilai-nilai budaya yang diwariskan oleh para leluhur bangsa ini mulai berangsur-angsur ditinggalkan oleh generasi muda kita (Acim A Situmorang :2019).

Kenyataan inilah yang membawa generasi muda saat ini berada dalam pengaruh perubahan sosial, dan pengaruh tersebut terjadi karena adanya suatu proses yang berlangsung secara terus menerus ketika generasi sekarang terus ber-proses dengan pesat tuntutan zaman, namun di sisi lain perubahan tersebut mengakibatkan masyarakat mulai membandingkan keadaan sekarang dengan keadaan masa lampau, sehingga dalam kelanju-tannya karakter anak bangsa mulai merosot dan dianggap tidak mempu-nyai nilai-nilai moral dan etika yang sesuai dengan idologi bangsa Indonesia (Salenussa:2019). Oleh karena itulah peranan pendidikan agama sangat dibutuhkan dalam upaya mengambil bagian dalam pola pengembangan dan pembangunan karakter anak bangsa yang berbasis multikultural sebagai sarana membangun kepercayaan, saling menghargai, saling memberi dan menerima, saling menyesuaikan diri dan sebagainya berdasarkan nilai-nilai kearifan lokal dan budaya, yang menghadirkan gereja, mesjid, sekolah-sekolah, lembaga kepemudaan dan masya-rakat sebagai institusi-institusi yang dapat dijadikan wadah strategis dalam mempersiapkan diri sebagai agenagen perdamaian dan aktor dalam membentuk komunitas iman lintas agama melalui aktifitas yang dilakukan secara bersama-sama.

Sejalan dengan itu, maka Pendidikan agama Kristen pun turut mengambil bagian dalam basis multikultural sebagai landasan pemahaman iman berbasis kearifan lokal untuk dijadikan instrument budaya yang efektif guna merevi-talisasi dan mentransformasikan nilai-nilai kearifan lokal (local wisdom) sebagai proses budaya yang seharusnya memiliki fungsi penting dalam mengantarkan generasi muda bangsa dalam upaya mengembangkan seluruh potensinya secara komprehensif (Triyanto:2014)

Bertolak dari pemikiran tersebut, sebagai individu yang berbudaya dan beragama, seharusnya mampu mengembangkan potensi budaya lokalnya dan lewat budaya lokal tersebut berbagai macam nilai dan norma dapat dijaga dan dilestarikan. PAK multikultural di sini diupayakan sebagai salah satu sumbangan pemikiran yang dalam isi dan penyampaiannya berhubungan dengan kebutuhan pembangunan di daerah setempat, tapi juga pembelajaran dalam upaya meningkatkan potensi spiritual, guna membentuk manusia yang beriman, berkarakter, dan mulia sesuai tantangan zaman yang semakin berkembang, seperti: keadaan di lingkungan sosial, di lingkungan alam, dan di lingkungan budaya perlu diajarkan kepada generasi muda saat ini sehingga dalam kelanjutannya lewat PAK Multikultural inilah pendidikan karakter dari anak bangsa dapat dibangun sebagai konsensus adatis dan tradisi komunitas yang berbasis keagamaan sebagai salah satu khazanah budaya yang perlu dilestarikan (Marlina :2013).

\section{Implikasi PAK Multikultural Bagi Generasi Muda Gereja di Era Revolusi Industri 4.0}

Revolusi industri 4.0 dalam sejarahnya, pertama kali dicetuskan oleh pemerintah Jerman untuk mem-promosikan komputerisasi manu-faktur, sehingga dalam perkemba-ngannya berimbas pada dunia pen-didikan di Indonesia agar dapat berinovasi dan kreatif dalam me-manfaatkan perkembangan tekno-logi yang ada, dengan berusaha untuk tetap mempertahankan pendi-dikan yang memiliki nilai-nilai karakteristik budaya lokal. 
Namun, sejalan dengan itu, tantangan revolusi industri 4.0 ini juga memberikan perubahan terhadap sistem sosial dalam pendidikan di Indonesia dan juga dalam masyarakat. Pertama, perubahan demografi dan nilai sosial. Kedua, pertumbuhan kompleksitas proses yang meliputi; keterampilan teknis, pemahaman proses, motivasi belajar, toleransi, pengambilan ke-putusan, penyelesaian masalah dan keterampilan analisis (Trisna :2019)..

Seiring dengan kemajuan ilmu pengetahuan dan teknologi, bukan tidak mungkin pendidikan dan segala sistemnya akan ikut menga-lami perubahan, misalnya dalam proses pembelajaran di kelas yang dulunya harus dilakukan tatap muka secara langsung, dengan adanya revolusi industri 4.0 ini pembe-lajaran di kelas dapat dilakukan se-cara online, selain itu adanya pe-manfaatan media sosial atau media pendukung lainnya. Semakin ma-junya ilmu pengetahuan dan teknologi dalam bidang pendidikan juga memberikan dampak negatif atau permasalahan baru yang dapat menghambat proses pendidikan di Indonesia. Salah satu dampak nyata permasalahan pendidikan di Indo-nesia saat ini adalah pendidikan ka-rakter yang mulai kehilangan arah ketika generasi muda sekarang mulai kehilangan jati dirinya sebagai anak bangsa bahkan lunturnya identitas nasional dalam diri generasi muda khususnya anak usia sekolah (Dwintari :2019). Hal tersebut dibukti-kan dengan masih adanya tawuran antar sekolah, diskriminasi kaum minoritas di lingkungan pendidikan, fanatisme, radikalisme yang saat ini menjadi permasalah di lingkungan pendidikan, kurangnya rasa toleransi, pandangan stereotipe bu-daya atau suku, seks bebas dan tindakan kriminal yang banyak dilakukan oleh generasi muda kita di usia sekolah.

Berbagai faktor yang mendasari munculnya berbagai tindakan kekerasan pun tidak dapat dielakan, seperti:

1. Kesenjangan atau kecemburuan sosial yang tidak dapat dipecahkan dengan penggusuran atau menghilangkan orang lain.

2. Memperjuangkan demokrasi dan keadilan, walaupun antara demokrasi dan kekerasan adalah sebuah kontradiksi. Karena demokrasi merupakan perwujudan kebebasan dalam mencapai keadilan, sedangkan kekerasan justru menyebarkan ketakutan dan konflik yang tidak menentu yang lebih berakar pada sempitnya pandangan individu.
3. Kekerasan bagian dari skala besar reformasi dan pembangu-nan bangsa.

4. Kekerasan merupakan tindakan spontan emosional individu atau kelompok.

5. Konflik agama, organisasi, kelompok, suku, dan fanatisme yang berlebihan.

Berbagai permasalahan yang timbul inilah, sebenarnya dapat dikatakan berimplikasi dari berbagai kemajuan ilmu pengetahuan dan teknologi. Sehingga pada kenya-taannya hal ini menjadi permasa-lahan yang menghambat kemajuan pendidikan bagi genereasi muda bangsa dan Negara ini. Oleh karena itulah, salah satu upaya untuk mencegah dan meminimalisir berbagai permasalahan tersebut adalah de-ngan meningkatkan pendidikan ka-rakter baik dalam bentuk pendi-dikan keagamaan maupun bentuk pembelajaran muatan lokal, di mana melalui pembelajaran tersebut ini, generasi muda gereja dapat membentuk identitas dirinya yang kuat melalui nilai-nilai toleransi yang tinggi dengan sesuai karak-teristik budaya bangsa guna memperkuat identitas nasional dikalangan generasi muda kita dalam menghadapi tantangan di era revolusi industri 4.0.

Menghadapi tantangan masa depan anak bangsa di era revolusi industri 4.0, maka pendidikan sebagai usaha sadar dan terencana dalam mewujudkan suasana belajar yang aktif dari setiap proses pembelajaran, akan berusaha menghentarkan generasi muda bangsa ini untuk dapat mengembangkan potensi dirinya dan menjadikan proses pembelajaran itu sebagai sarana untuk mengerti, memahami dan mengetahui sesuatu, serta lebih kritis dalam berpikir (Wedan 2016).

Sejalan dengan pemikiran tersebut bagi generasi muda gereja, PAK multikultural sangat perlu dikembangkan sebagai salah satu bentuk pembelajaran yang dapat mengarahkan generasi muda khususnya generasi Muda gereja di Maluku, dalam upaya membentuk karakter yang mampu mengenal jati dirinya yang unik sebagai warisan leluhur. Menjadikan PAK multikultural sebagai alat dalam upaya mengembangkan ilmu penge-tahuan, keterampilan, kebiasaan, dan sikap-sikap yang dapat membuat seseorang menjadi lebih baik, maka hal ini menunjukkan bahwa PAK multikultural juga merupakan sarana untuk melakukan transmisi dan transformasi baik nilai maupun ilmu pengetahuan dalam rangka menanamkan dan mengembangkan karakter anak bangsa maupun generasi muda gereja untuk menjadi teladan dan panutan yang baik di kemudian hari berdasarkan ajaran Kristiani dan 
nilai-nilai kearifan lokal budaya yang telah diwariskan oleh para pendahulu (Sudrajat:2011).

PAK multikultural dalam era revolusi industri 4.0 ini kemudian berimplikasi bagi generasi muda gereja untuk terus berinovasi lewat berbagai proses pembelajaran dalam upaya memfasilitasi tantangan dan problematika yang terjadi pada generasi muda di era revolusi industri 4.0. Hal ini menjelaskan bahwa pembelajaran yang disampai-kan bukan saja akan bermuatan lokal, namun nilai-nilai yang disampaikan kiranya dapat disesuaikan dengan konteks hidup beragama sehingga hal tersebut dapat diimplikasikan dengan cara menselaraskan pengetahuan melalui PAK multikultural yang nantinya dapat memberikan inovasi dalam upaya menanamkan nilai-nilai kearifan lokal dalam menselaraskan kemajuan teknologi 4.0 dengan tetap melestarikan, menjaga, dan menga-wetkan nilainilai budaya dan agama tersebut sebagai warisan leluhur yang bernilai kebersamaan, cinta damai, dan saling menghargai dalam konteks multikultural dan pluralis.

Peranan PAK multikultural inilah yang kemudian dijadikan to-lak ukur dalam memberikan sum-bangan pemikiran bahwa ketika generasi muda bangsa dan masyarakat yang multikultural ter-sebut mengalami perubahan para-digma karena kemajuan teknologi informasi yang semakin meluas, maka upaya yang dapat dilakukan adalah memberikan inovasi dalam pembelajarannya, agar dalam kelanjutannya PAK multikultural ini da-pat dijadikan sebagai alat pemba-haruan dalam mengatasi permasalahan yang terjadi di masya-rakat, sehingga generasi muda gere-ja tidak tergerus oleh kemajuan teknologinya, melainkan mampu menselaraskan kemajuan teknologi tersebut dengan kondisi multikul-tural yang terjadi di masyarakat.

\section{Simpulan}

Pendidikan Agama Kristen (PAK) pada hakikatnya lebih mengarah pada usaha yang dilakukan secara terencana dan kontinyu dalam mengembangkan kemampuan generasi muda gereja untuk melalui pertolongan Roh Kudus, mampu memahami dan menghayati kasih Allah dalam diri Yesus Kristus yang dinyatakan dalam hidup seharihari, baik terhadap sesama maupun lingkungan hidupnya. Dalam kon-teks multikultural, maka PAK berperan sebagai Pendidikan Agama yang dapat mengambil bagian dalam pola pengembangan dalam memba-ngun keadilan dan perdamaian ber-basis multikultural sebagai sarana membangun kepercayaan, saling menghargai, saling memberi dan menerima, saling menyesuaikan diri dan sebagainya berdasarkan nilai-nilai kearifan lokal dan budaya, yang menghadirkan gereja, mesjid, sekolahsekolah, lembaga kepemu-daan dan masyarakat sebagai institusi-institusi yang dapat dijadikan wadah strategis dalam mempersiapkan diri sebagai agen-agen perdamaian dan aktor dalam membentuk komunitas iman lintas agama melalui aktifitas yang dilaku-kan secara bersama-sama.

\section{Saran Dan Rekomendasi}

Berdasarkan pembahasan di atas, maka penulis memberikan saran dari hasil penelitian. PAK multikultural dalam bingkai era revolusi industri 4.0 lebih berperan guna memberikan sumbangan pemikiran bahwa ketika generasi muda bangsa dan masyara-kat yang multikultural tersebut me-ngalami perubahan paradigma karena kemajuan teknologi infor-masi yang semakin meluas, maka upaya yang dapat dilakukan adalah memberikan inovasi dalam pembe-lajarannya, agar dalam kelanju-tannya PAK multikultural ini dapat dijadikan sebagai alat pembaharuan dalam mengatasi permasalahan yang terjadi di masyarakat, sehingga generasi muda gereja tidak tergerus oleh kemajuan teknologinya, melainkan mampu menselaraskan kemajuan teknologi tersebut dengan kondisi multikultural yang terjadi di masyarakat.

\section{Ucapan Terima Kasih}

Pada kesempatan ini, terimakasih saya ucapkan kepada redaktur yang telah memberikan masukan yang berharga sehingga tulisan ini dapat disajikan di jurnal Institutio. Terimakasih juga saya ucapkan kepada seluruh dewan redaksi jurnal Institutio yang sudah memberikan ruang diskusi. Semoga bantuan dan dukungannya mendapatkan balasan yang sebanyak-banyaknya dari Tuhan kita Yesus Kristus, Amin.

\section{Pustaka Acuan}

Acim, A., Situmorang, R., \& Salenussa, B. J. . (2019). Reviewing Maluku's Local Culture through Multicultural Education Approaches. Asia Proceedings of Social Sciences. https://doi.org/10.31580/apss.v4i2.750

Dwintari, J. W. (2018). Urgensi Pendidikan 
Kewarganegaraan Berbasis Multikultural dalam Pembinaan Keberagaman Masyarakat Indonesia. Civic-Culture: Jurnal Ilmu Pendidikan PKn Dan Sosial Budaya.

Ibrahim, R. (2013). Pendidikan Multikultrural: Pengertian Dan Relevansinya Dengan Tujuan Pendidikan Agama Islam. Addin.

Lestari, G. (2015). Bhinnekha Tunggal Ika : Khasanah Multikultural. Jurnal Pendidikan Pancasila Dan Kewarganegaraan.

Marliana; Hikmah, N. (2013). Pendidikan berbasis muatan lokal sebagai sub komponen kurikulum. Jurnal Dinamika Ilmu, 13(1), 105119.

Moleong, L. J. (2017). Metodologi Penelitian Kualitatif (Edisi Revisi). In PT. Remaja Rosda Karya.

Muhammad Latif Fauzi. (2005). Konsep Negara Dalam Perspektif Piagam Madinah dan Piagam Jakarta. Jurnal Al-Mawarid.

Nuhamara, D. (2018). Pengutamaan Dimensi Karakter Dalam Pendidikan Agama Kristen. Jurnal https://doi.org/10.25278/jj71.v16i1.278

Ode, S. (2015). Budaya Lokal Sebagai Media Resolusi dan Pengendalian Konflik di Provinsi Maluku (Kajian,Tantangan dan Revitalisai Budaya Pela) Samsul Ode. Jurnal Politika.

Pamungkas, C. (2014). Agama, Etnisitas, dan Perubahan Politik di Maluku: Refleksi Teoretik dan Historis. Masyarakat Indonesia.

Salenussa, B. J. M., Suriani, Yufiati, \& Mataheru, N. M. (2019). Development of integration education model pela-gandong local based on local content in primary schools in Ambon City. International Journal of Recent Technology and Engineering. https://doi.org/10.35940/ijrte.B1027.0982S919

Sudrajat, A. (2011). Mengapa Pendidikan Karakter? Pendidikan Karakter. https://doi.org/10.21831/jpk.v1i1.1316

Suharsono, S. (2017). Pendidikan Multikultural. EDUSIANA: Jurnal Manajemen Dan Pendidikan Islam. https://doi.org/10.30957/edusiana.v4i1.3

Supriatin, A., \& Nasution, A. R. (2017). INSTITUTIO: JURNAL PENDIDIKAN AGAMA KRISTEN VOL V NO II
Implementasi Pendidikan Multikultural Dalam Praktik Pendidikan di Indonesia. Elementary: Jurnal Ilmiah Pendidikan Dasar. https://doi.org/10.32332/elementary.v3i1.785

Tilaar, H. A. R. (2017). Pendidikan untuk Mengembangkan Identitas Bangsa. Abad: Jurnal Sejarah.

Trisna, B. N. (2019). Education 4.0 Perubahan paradigma dan penguatan kearifan lokal dalam pembelajaran matematika. Math Didactic: Jurnal Pendidikan Matematika. https://doi.org/10.33654/math.v5i1.519

Triyanto. (2014). Pendidikan seni berbasis budaya. Imajinasi: Jurnal Seni, VIII(1), 33-42. Retrieved from https://journal.unnes.ac.id/nju/index.php/imajin asi/article/view/8879/5818

Tualeka Zn, H. (2015). Kearifan Lokal PelaGandong di Lumbung Konflik. El-HARAKAH (TERAKREDITASI). https://doi.org/10.18860/el.v0i0.457

Utomo, B. S. (2017). Revolusi Guru Pendidikan Agama Kristen dalam Mentransformasi Kehidupan Siswa. DUNAMIS: Jurnal Penelitian Teologi Dan Pendidikan Kristiani. https://doi.org/10.30648/dun.v1i2.111

Wedan, M. (2016). Pengertian Pendidikan dan Tujuan Pendidikan Secara Umum. 